Отримано: 10 квітня 2019 року

Прорецензовано: 22 травня 2019 року

Прийнято до друку: 23 травня 2019 року

e-mail: klymenova270707@ukr.net

DOI: $10.25264 / 2519-2558-2019-6(74)-172-174$
Olena Klymenova, Olga Kondrasheva. Formation of intercultural competence in course of teaching foreign language at higher schools for future lawyers. Наукові записки Національного університету «Острозька академія»: серія «Філологія». Острог: Вид-во НаУОА, 2019. Вип. 6(74), червень. С. 172-174.

\footnotetext{
Olena Klymenova,

УДК $378: 34$

Associate professor of Department of Ukrainian studies and foreign languages, Dnipropetrovsk State University of Internal Affairs Olga Kondrasheva,

Assistant professor of Department of Ukrainian studies and foreign languages, Dnipropetrovsk State University of Internal Affairs
}

\title{
FORMATION OF INTERCULTURAL COMPETENCE IN COURSE OF TEACHING FOREIGN LANGUAGE AT HIGHER SCHOOLS FOR FUTURE LAWYERS
}

The peculiarities of language teaching to the students whose future profession is area of law are considered in the article. The ways and means of intercultural competence formation with future law experts in the process of their foreign language training are the subject of investigation. Intercultural competence is considered as the result of mastering the general cultural, linguistic, value-semantic, country-study, socio-cultural and psychological competencies.

The article draws our attention to implementation of international standards in academic process. It is stressed that the major principle of foreign language training should be the principle of mutual enrichment with the strengths of foreign cultures together with preservation of own originality and integrity.

It is noted that language skills development with lawyers is closely connected with correct terminology application, grammar constructions proper use, avoiding vague or multi-valued meanings. The paper is concerned with variety of methodological approaches that are used in the process of foreign language training.

The authors of the article investigate methods and forms of the academic discipline "Foreign language for special purposes". The series of exercises is suggested to improve foreign language training with future lawyers. It is proved that foreign language professional competence can be realized through the activity covering such language actions as getting information from the world internet network, making presentations, written and oral information exchange (e-mailing), expressing ideas and discussing problems etc.

It is of great interest to the language teachers who are expected to guide students in the acquisitions of various skills, contributing to the development of their knowledge and understanding of a target language and culture, helping them reflect on their own culture as well.

It is summarized that all the issues mentioned above demonstrate the fact that position of the academic discipline "Foreign language for special purposes" has strengthened in higher education of Ukrainian lawyers nowadays as well as great importance for looking for new effective ways to train highly qualified lawyers.

Key words: communicative aspect, academic process, language and professional education, language competence, language means, terminology of law, professional communication.

Клименова Олена Миколаївна,

дочент кафедри украйнознавства та іноземних мов, Дніпропетровський державний університет внутрішніх справ Кондрашева Ольга Василівна,

стариий викладач кафедри українознавства та іноземних мов,

Дніпропетровський державний університет внутрішніх справ

\section{ФОРМУВАННЯ МІЖКУЛЬТУРНОЇ КОМПЕТЕНТНОСТІ В ПРОЦЕСІ ІНШОМОВНОЇ ПІДГОТОВКИ МАЙБУТНІХ ЮРИСТІВ В ВИЩИХ НАВЧАЛЬНИХ ЗАКЛАДАХ}

У статті розглянуто особливості мовної підготовки фахівиів у галузі права в вищих навчальних закладах, досліджено шляхи формування міжкультурної компетентності фахівців з права у процесі іншомовної підготовки. Зазначено, щзо пріоритетним завданням вищої школи в Украӥні є підготовка компетентного спеціаліста - особистості, яка має високий рівень комунікативної компетениії. Досліджено завдання, методи і форми навчальної дисиипліни «Іноземна мова за професійним спрямуванням». Окреслено шляхи формування мовної компетенції майбутніх юристів. Запропоновано ряд вправ для удосконалення іншомовної підготовки студентів з урахуванням правової спеиифіки.

Ключові слова: комунікативний аспект, навчальний процес, мовно-фахова освіта, мовна компетенція, мовні засоби, юридична термінологія, професійне спілкування.

Economic, social and political reconstructions, general worldwide changes, legislation basis formation in Ukraine as an independent state require new approach to training experts in the area of law. Ukrainian society is trying to construct contemporary legal state and needs highly qualified experts in the area of law. Such kind of experts needs to become proficient in writing, speaking, reading and listening in foreign language in their business sphere. Thus, the system of language training requires fundamental revision and should be aimed at professional and practical activities of future lawyers.

The challenge of foreign language training with experts in law, in this case, is the radical changes required in the process of foreign language training of future experts in law and adjustment of components of this training to the new professional requirements of the trainees. The more so, that language skills development with lawyers is closely connected with correct terminology application, grammar constructions proper use, avoiding vague or multi-valued meanings. We should remark contemporary law terminology as an accumulation of nominations of legal phenomena and notions. It functions as united conventional area in language and legal spheres of legislation, in business papers, and law academic disciplines. Law terminology has complex, dynamic character and it is considered to be a very important constituent of literary language of any language lexis.

The issues of competencies formation with future lawyers in the process of their professional training in higher schools are investigated in the works by O. Gomzyakova (multicultural competence), D. Demchenko (professional foreign language competence), V. Savishchenko (deontological competence), I. Kharchenko (terminological competence), S. Illina (professional competence), O. 
Kalyta, Yu. Marchenko, N. Kozhem'yako, L. Pysarenko, M. Tsenko (communicative competence), L. Morskoi (mediator competence), O. Fedorchuk (professional and informational competence) etc.

Scientists believe that intercultural competence of a future expert is an essential element of both professional competence and general culture.

Development of social and cultural competence as an integral part of intercultural competence in the process of foreign language training is the subject of investigation in the works by N. Borysko, O. Gomzyakova, G. Elizarova, O. Lytvynenko, O. Myrolyubov, A. Mol'.

The subject of the article is to determine the peculiarities of foreign language training at a higher school for future lawyers, investigating the ways of intercultural competence formation with future law experts in the process of foreign language training,

Under conditions of higher education aiming at all-round and harmonic individual's development, at strengthening bonds between educational content and future occupation of the trainees more and more importance is gaining the content of higher education in particular, which effects language competence formation with the trainees [4, p. 16]. According to "The Law on higher education", National doctrine of education development, State standard of higher education, The European Union general recommendations on language education (EUGR), the priority objective of higher school in Ukraine is to train the expert of high quality in the field of law. We need to form the individual, who possesses the competences required for understanding nature and functions of law, for understanding functions and operation of the main law institutions, for applying law to regulate social relations in society legally. The students of Law higher schools ought to be ready to serve society and to follow the principles of human dignity and professionalism, the principles of justice, objectivity, sympathy and high moral standards.

Versatility and multi-vector nature of the notion" language education" conditions causes separating out two main directions, which determine foreign languages learning. The process of language training in non-philological higher schools anticipates leaning terminology and professional lexis and mainly takes place in the classroom at the lessons of studying the academic course "Language for special purposes" (Ukrainian and English) [3, p. 2]. The fact is that law terminology grounds on logical and conceptual connections and reflects both inter-brachial and inter-scientific relations. Consequently, the importance of their correct translation from one language into another is great while translating special and scientific texts. Evidently, there is not any other occupation where in the course of speech external form of utterance has such a vital significance as in law. This is conditioned by expansion of linguistics into legal sphere of social life. Contemporary ideas of a language role (social communication) prove the fact, that junction of language and law is not limited by only this aspect and needs both further investigation and development of a broad educational program of law and linguistic education as a whole [1, p. 27].

The other important problem is implementation of international standards in academic process. In terms of international standards, the level of our experts' language knowledge needs to be in line with the requirements of the European Union general recommendations on language education (EUGR). European Council supports methods of teaching and education, which help our youth to get knowledge, skills and experience required for gaining independence of thinking, communication with the colleagues from different countries. Intercultural competence as an entire system synthesizes totality of knowledge (linguistic, social and cultural, professional) skills (verbal and non-verbal communication, general cultural and special cultural) and focus of values. Anticipating developed readiness of an individual to participate in intercultural communication and professional communication in particular, intercultural competence is considered as a result of mastery of a number of competencies such as general cultural, linguistic, value and notional, regional geographical, social and cultural, and psychological. "Systemic quality of training specialists will meet the requirements of international standards in terms of basic competencies of contemporary expert in the area of law, as international communication is not a polylog in only such spheres as tourism, culture, art, daily life, but it is also communication on a certain professional level" [6, p. 8].

Language comes out as the basis of communication, combining different ways of communication and forms of social consciousness. It accumulates basic cultural and historical values of humanity and indicates the level of society development. The point is that there is an individual, who is both a language speaker and a culture representative, who stands between language and a real world. This fact is grounded in scientific works and publications by such authors as O. Goncharova, O. Kovalenko, V. Komarnyts'ka, A. Maslova, S. Nilkolaeva T. Oliynyk. It is an individual, who perceives the world and makes aware of it through his/her senses and shapes his/her ideas of it. These ideas, in their turn, are comprehended in notions, judgments and conclusions, which can be addressed to other people. Experience proves the fact that it is much more difficult to reconstruct individual's national mentality than to learn some linguistic forms. Therefore, the method of teaching language together with teaching culture of the native speakers' country is of primary importance in intercultural competence formation. The abovementioned statements give grounds to the idea, that we cannot form proper level of intercultural competence with future lawyers without introducing to them cultural elements of the country, which language they study. Cultural constituent in the content of foreign language training favors formation of the conscious and tolerant attitude to cultural differences, stirs linguistic, cognitive and social development of a future lawyers. Thus, a future lawyer's development will be rather effective at the foreign language lessons, provided that a teacher performs poly-cultural mission of the academic discipline.

The major principle of foreign language training should be the principle of mutual enrichment with the strengths of foreign cultures together with preservation of own originality and integrity. It is the principle, which determines intercultural communication and forms the readiness to such kind of intercultural communication, establishing the pedagogic core of foreign language training of future lawyers. Results of the investigation made show that there are a number of forms, methods and techniques, which favor successful development of intercultural competence and produce positive attitude to foreign language studies. We can mention some of them such as special programs of preparing students for intercultural interaction, some methods of teaching for developing students' critical thinking, some creative and values technologies, psychological and diagnostic training. It is worth mentioning tolerance training, education projects, drama plays, debates, role playing, discussions, creative tasks, professional situations and interactive tasks, interview method, "Portfolio" and special techniques such as "Capsule of Culture", "Cultures' Collision", "Behavior of a Mediator between Cultures", "Cultural Adaptation" etc. 
Intercultural competence is one of the important constituents of professional competence of a lawyer. It is the accumulation of certain knowledge and skills. Such skills include knowledge of native and foreign cultures, knowledge of foreign language and such skills as to apply adequate styles in communication and to identify them in situations of intercultural interaction, to interpret the phenomena in communicative activity and behavior from the point of view of cultural determinants, to understand the main principles of intercultural and interpersonal communication and follow them, to break through barriers of cultural differences. They also include the skills to apply strategies to avoid misunderstanding in communication with foreign cultures' representatives, to take into account psychological peculiarities of foreigners (tolerant attitude to foreign cultures' representatives, to cultural differences in behavior, mentality, customs etc.). One of the very important skills is to be able to compromise, to reach mutual understanding and to be aware of the fact that there is dependence of an individual's mentality of the culturally conditioned cognitive schemes. The need in training experts prepared for constructive interaction in the area of intercultural communication directs and stimulates pedagogy to look for effective ways and means of forming the individual's quality mentioned above.

Foreign language study is a long and rather complicated process, which takes a lot of time and efforts. Status of the academic discipline "Foreign language for special purposes" is undergoing some changes. It exceeds the limits of the academic process and becomes the tool in training the expert of a new updated kind, who is ready for self-education and is capable to acquire cultural heritage of the country, which language he/she studies, to correlate it with the native culture and with its place in the world historical context [3, p. 30].

The main aim of the academic discipline "Foreign language for special purposes" is to teach trainees to carry out business communication in the sphere of their professional activity, performing their professional responsibilities. It means to develop their communicative competence and namely such communicative skills as speaking, writing, listening and reading on their professional themes, on some general topics. Forming communicative competence with the trainees in vocational education, we need to develop communicatively active personality, who is able to perform active, correct and successful intercultural communication. The state educational standard of vocational higher education sets clear requirements to the academic discipline "Foreign language for special purposes" such as: 1) communicative bases: phonetics, lexis, phraseology, grammar; 2) bases of business communication on the specialty; 3 ) professional lexis; 4) phrazeological constructions and terms; 5) translation technique (with dictionary) of professionally oriented texts; 6) professional communication. The notion "foreign language competence" in vocational higher schools is connected with communicative language competences, which in their tern include some constituents like motivational, moral and ethical etc. directed to creation, action and result [5, p. 343]. Thus, specific character of foreign language professional competence is determined by professional focus. Reading literature on professional and scientific issues, getting new information for themselves, the students level up their professional expertise. Foreign language professional competence can be realized through the activity covering such language actions as getting information from the world internet network, making presentations, written and oral information exchange (e-mailing), expressing ideas and discussing problems etc. Students' self-work organization is one of the most important constituents of teaching the academic discipline. It is directed to deepening and systematizing students' knowledge of both foreign language and profession and develops skills of scientific investigation.

To conclude, we should remark that all the issues mentioned above demonstrate the fact that position of the academic discipline "Foreign language for special purposes" has strengthened in higher education of Ukrainian lawyers nowadays. Our State managers acknowledge the fact that foreign language mastering by the experts in law has social and political importance for our young sovereign State, striving to join European developed democratic community. It is also of great importance for looking for new effective ways to train highly qualified lawyers. This approach will allow us to meet Ukrainian State's needs in foreign languages speaking experts in law.

\section{Література:}

1. Дементьева Т. Г. Подготовка к межкультурной коммуникации при обучении иностранным языкам специалистов. Межккльтурная коммуникация и профессионально ориентированное обучение иностранным языкам: Материалы V Междун. науч. конф. Минск, 2011. $191 \mathrm{c.}$

2. Куликова Л. В. Межкультурная коммуникация: теоретические и прикладные аспекты. Красноярск, 2004.196 с.

3. Ганніченко Т. А. Формування комунікативної компетенції майбутніх економістів засобами дидактичної гри у процесі мовної освіти: дис. канд. пед. наук. Херсон: Херсонський державний університет, 2009. 262 с.

4. Дроздова І. П. Формування мовної компетенції у студентів технічних спеціальностей вищих навчальних закладів Східної України (на матеріалі курсу ділової української мови): автореф. канд. пед. наук. Київ: Інститут педагогіки АПН України, 2001. 24 с.

5. Коммуникативная ориентированность обучения иностранным языкам в неязыковом вузе: Метод. рекомендации для преподавателей. Москва: МГЛУ, 2012. 72 с.

6. Леонтьев А. А. Коммуникативность: пришло или прошло ее время? Иностр. языки в школе. 2016. № 5. С. $22-33$.

7. Тер - Минасова С. Г. Доклад на Международной конференции «Языки в современном мире». Вестник Моск. Ун-та. Сер.19. Лингвистика и межкультурная коммуникация. 2002. №1.

8. Pieho H. E. Some basic problems of communicative foreign language learning. Report on Council of Europe workshop. 2016. 2 April, FRG. P. 6.

9. Гончарова О. А., Маслова А. В. Формування міжкультурної компетентності студентів немовних спеціальностей в процесі навчання іноземної мови. Науковий вісник Мелітопольського державного педагогічного університету імені Богдана Хмельницького. Серія: Педагогіка. 2010. № 5. URL: https://goo.gl/2Wqibq. 